\title{
Using Muted-Video Enactments to Develop Sociolinguistic Awareness
}

Sessiz Film Sahnelerinin Toplumdilbilim Konusunda Bilinçlendirme Amaçlı Kullanılması

\author{
Seher Balbay \\ Middle East Technical University, Turkey \\ Gökce Erkan \\ Middle East Technical University, Turkey
}

\begin{abstract}
Silent films have long been shown during language classes to ease contextual and pragmatic acquisition. Equally empowering, muted videos are commonly used to help students to learn culture-laden and fixed expressions. They report to appreciate and enjoy using visual cues to understand and then appropriately use unfamiliar language, and especially to cope with novel situations such as job interviews. This study analyses students' voiceover responses to a series of muted videos shown during their participation in an oral communication skills course intended to develop their sociolinguistic awareness. The researchers wanted to know the extent to which students benefited from the muted video task. A mixed method design was used to identify the most common challenges learners face with when using culture-laden expressions. Both self-developed, online pre and post-test, and focus group interviews were used as data collection tools. The participants, selected according to the convenience sampling method, were students studying at an English-medium state university in Turkey and taking a compulsory oral communications-oriented English course. Afterwards, participants were seen to have developed sensitivity towards using context-bound fixed phrases. The research data was also useful in helping to pinpoint common challenges for learners when using contextually fixed phrases in English.
\end{abstract}

Keywords: muted videos, pragmatics, sociolinguistics, contextual language, fixed phrases

Öz

Sessiz filmlerin İngilizce öğretilen sınıflarda öğrencilerin dil üretimi için kullanılması özellikle bağlamsal dilbilim üzerine yoğunlaşıldığında yeni bir yöntem değildir. Sessiz film sahnelerinin kullanımı İngilizce dil öğretimi sınıflarında öğrencilere durumsal doğru dil bilincini geliștirme amacı ile uygulanan teknikler arasındadır. Bu tür kültüre bağlı sabit ifadeler İngilizce öğrenen öğrenciler için mezuniyetleri sonrasında içinde olacakları iş nedenli hareketliliklerinde önem teşkil edecektir. Bu nedenle, bu çalışma İngilizce sözlü iletişim becerileri dersinde toplumdilbilim konusunda bilinçlendirme geliştirilmesi amacı ile dersin öğrencilerinden istenmiş olan sessiz film sahnelerine seslendirme yapılmasının beklendiği bir girişimin etkilerini araştırmaktadır. Çalıșma, öğrencilerin sessiz film aktivitesinden ne derecede yararlandıklarını ve öğrencilerin kültüre bağlı sabit ifadeleri kullanırken en sık karşılaştıkları zorlukları belirlemek için karma yöntemli araştırma deseni ile inceleme yapmaktadır. Veri toplama yöntemleri olarak hem araştırmacılar tarafından geliştirilmiş, çevrimiçi ön-ardıl sınav tasarımı hem de hedef grup mülakatları kullanılmıștır. Kolayda örneklem yöntemi kullanılarak

CUJHSS, December 2021; 15/2: 259-275.

(C) Çankaya University ISSN 1309-6761 Printed in Ankara

Submitted: May 31, 2021; Accepted: October 28, 2021

ORCID\#: 0000-0001-6276-053X; 0000-0003-4248-9257

seherbalbay@gmail.com 
seçilmiş olan katılımcılar Türkiye'de İngilizce dilinde eğitim veren bir devlet üniversitesinde tüm lisans eğitimi veren bölümlerde zorunlu bir ders olarak sunulan İngilizce sözlü iletişim becerileri dersini alan öğrencilerdir. Çalışma sonucunda uygulanan müdahale sonrası katılımcıların duruma bağlı sabit ifadelerin kullanımına karşı bir duyarlılık geliştirdikleri ortaya çıkmıştır. Çalışma verileri ayrıca öğrencilerin İngilizce konuşurken kullandıkları duruma bağlı ifadeler ile ilgili en sık karşılaştıkları zorluklara da işaret etmiștir.

Anahtar Kelimeler: sessiz filmler, bağlamsal dilbilim, toplumdilbilim, bağlamsal dil, sabitleşmiş ifadeler

\section{Introduction}

The interaction between language and culture was elaborated on in the 1950s by Edward Sapir and Whorf. Their hypothesis, suggests that languages shape the conceptions their speakers form in their minds, with the strongest support to this coming from culture-dependent vocabulary items (Mandelbaum). While this idea hypothesis has ever since stimulated debate among linguists as to how language and culture processes interact, we know that, especially at the lexical level, words play a significant role in developing cultural patterns and values. The effect of culture on language is observable in our utterances, multi-word combinations, collocations, phrasal words, idiomatic expressions, "metaphorical expressions, proverbs, familiar quotations, catchphrases, clichés, slogans, expletives, and discourse markers." (Skandera 5). The present paper explores the impact of an intervention specifically designed to address the nonnative speakers 'language production. Itself a process that requires sensitivity towards formulaic phraseology. The researchers do not promote the use of a standardized, native speaker British/American English. Instead, authentic language is used to avoid communication breakdowns and misunderstandings.

\section{Literature Review}

In the 1970s, research in language teaching distinguished between "linguistic and communicative competence" (Paulston 348). Communicative competence, a term coined by Dell Hymes, covers the potential abilities of the language learner not only in constructing grammatically accurate sentences but also socially appropriate sentences when negotiating meaning in a given context (277-278). Social-constructivist perspectives especially have seen interactive communication as an indispensable construct of language learning and developing communicative competence. Social contact and keeping the channels of communication open are indispensable requirements of the language learning process (Brown, "Principles of Language Learning and Teaching"). Yet, when communication is the issue, many other aspects of language are in effect since communicative competence is a complex construct that requires explicit knowledge of the culture of the target language and an awareness of culturespecific expressions. While the emphasis on communicative competence does not mean to overlook the importance of structure, in addition to characteristics of communication - social, cultural, and pragmatic implications of language are also emphasized in materials that are designed to develop communicative 
competence. English language classrooms have consistently tried out varying techniques to develop communicative competence.

Communication always takes place in a context that essentially predetermines what language is "appropriate" to use in that situation. Tasks that require students to analyze a given context as they decide on their language use are expected to raise an awareness of contextually appropriate language use, rather than merely grammatically accurate but inauthentic language use. This is a crucial, personal and variable learning experience. Turn-key moments, which when taken together, instill life-long insights to the complexity of the language they are learning. With this rationale in mind, this paper aimed to evaluate the impact of an intervention, which required the production of English in a contextembedded communication. The intervention featured a specific technique that requires the student to independently view muted videos obtained from films and to then discuss how their responses to the situations they observed informed both their acquisition of authentic language and sociolinguistic awareness.

\section{Communicative competence and context-embedded tasks}

Meaning is dependent on numerous factors arising from the context in which language is used. We also know that when language learning is context-reduced, as was often the case in earlier classrooms, the learner takes longer to learn. Discussions of communicative competence in the language classroom date back to the 1980s, with the work of Canale and Swain who described the functions of language under four main categories (27); "Grammatical competence" with reference to knowledge of morphology, syntax, grammar, semantics, and phonology; "Discourse competence" refers to inter-sentential relationships that are cohesive and make sense as a whole;" Sociolinguistic competence" emphasizes the cultural values inherent to language, the roles speakers adopt, and the functions of their utterances in spoken language, or the functions of the discourse used in certain culture laden circumstances; "Strategic competence" concerns the compensatory strategies used to the user cope with misunderstandings or gaps in communication, such as paraphrasing, repetition, or hesitation. These strategies facilitate overcoming the breakdowns in interactive communication and helps participants in a conversation to negotiate the intended meaning, which is known as "illocutionary competence."

In everyday conversations, a statement may function as a question, proposition, expression of agreement or disagreement, a rephrase asking for clarification depending on the surrounding context and the intonation, or even facial expressions and gestures which carry significant cultural meaning is specific contexts. Such features are of course indispensable to language competence in general as they enable us to recover from breakdowns in communication and perceived meaning; as" perlocutionary competence" may not always match what the speaker meant. Clearly, these recover devices have arisen because what may have initially brought confusion is not always rooted in structural, syntactic, or semantics-related problems. It may simply be due to misunderstandings of "speech acts" - a term coined by John Austin in 1962 
(Woods 21). Such acts are utterances that are most usually considered as actions expressing promises, ordering something, giving greetings, issuing warnings, making invitations, extending congratulations, and so on. As these combinations of fixed expressions and speech acts are culturally and contextually-dependent, it falls to the language teacher to both interpret and encourage their students ' acquisition of appropriate language and contextual awareness of the culture they have engaged with.

It follows that pragmatics has developed as an important aspect of linguistics that dwells on context-dependent utterances; and essentially how context contributes to meaning. Study of the pragmatic contexts of discourse aim to identify the factors that contribute to the functions of utterances - be they for purposes such as making compliments, responding to perceived insults, making apologies, etc. Clearly such aspects are vital to successful communication, however the authentic contexts in which language functions as slang, jargon, jokes, or folkloric expressions are largely absent from traditional second language textbook tasks, which are mostly given over to emphasizing formal and structural accuracy. Notional-functional approaches to language teaching refer to the authentic contextual language of exchanging personal information, giving commands, apologizing, or thanking via interactive tasks, such as role-playing or information-gap activities, but the fact that a function is covered does not guarantee to cover authentic language either (Wilkins). However, with the integration of technology into the language teaching arena, most language learners have been exposed to authentic, context-dependent speech acts via the video sources available online, with television shows and film being the most widely used sources (Berns 328).

Non-native speakers of English can be exposed to naturally occurring language by simply analyzing the authentic language used in movies. Teachers can emphasize the utterances that may be challenging to their non-native students by scrutinizing cross-cultural aspects of utterances. The pragmatic effect of context on strings of sentences changes their function and makes the sentences much less independent of their formal structure. Cross-cultural contrasts play a major role in foreign language speakers sounding "foreign" even when they have native-like accents because of the directly translated fixed expressions that they use, replacing the actual words with their generic or coined counterparts, awkward paraphrasing, or "foreignizing" the native language vocabulary making the words sound as if they belong to the target language. When conventions of the target language are ignored, the illocutionary force, that is, the intended meaning, may not match the perlocutionary force, that is, the effect on the conversation partner, no matter how accurate the grammar of the sentences may be. Politeness, formality, complementing, thanking, and facesaving conventions are very touchy and, therefore, open to misunderstandings during the interlanguage period. Such styles vary considerably not only between the speakers of different languages but even within one's own language and culture - depending on different local cultures. 
Language proficiency does not only concern structural accuracy but the contextual appropriation of the utterance. Being a proficient user of a language entails pragmatic competence, as well as developing both linguistic proficiency and sociocultural awareness and attaining a useful understanding of how language functions in social and cultural contexts (Kasper and Roever 317-318). Aside from this pragmatic knowledge, proficient language users should also care about non-verbal communication. "We communicate so much information nonverbally in conversations that often verbal aspects of the conversation are negligible" (Brown, "Teaching by Principles"). The intonation in our utterances, the gestures and body language, and the context determine most of the meaning conveyed. It is not uncommon to hear unnatural, non-native language in English classes that sounds mechanical without the nonverbal clues of authentic circumstances. Edward Hall coined the phrase "silent language" to refer to means of communication that go beyond words to cover expressions that are usually culture-bound. Kinesics, folding arms, crossing your legs, the way you walk, etc., convey meaning and intention to the conversation participant just as much as language does, or sometimes more so. The importance of non-verbal communication has been emphasized in Conversation Analysis studies, too (DeCapua and Wintergerst).

It is known that two of the most influential cognitive processing approaches proposed in second language acquisition are Smith's (1980) consciousnessraising and Schmidt's noticing hypothesis. According to Smith, "consciousnessraising" represents a deliberate focus on the formal properties of language (input), which will alter the learner's mental state as all input turns into the intake in time. Similarly, Schmidt also proposed that for learning to occur, learners first need to notice the language structures in their actual contexts to make sense of them ("Consciousness", 25-26). Given that, consciousness-raising or noticing plays a crucial role in enhancing the properties of language. Thereafter, Rose introduced video-prompts as an approach to promote pragmatic consciousness-raising in language classes ("Pragmatic Consciousness-raising" 57-58). Being aware of some limitations of video usage, such as many of them being scripted rather than having natural utterances filmed in authentic circumstances, she still believes that videos provide language used in rich, recoverable contexts, which can be exploited by both native and non-native teachers of English to raise pragmatic consciousness (Rose "Pragmatic Consciousness-raising" 58).

Elsewhere, many researchers have found that it can be a challenge for learners to understand what is pragmatically acceptable in different cultural contexts such as the classroom (Barron 521, Davies and Tyler 154). To address such cultural concepts in language classes, it is suggested that language teachers should adopt specific output-focused approaches to draw students 'attention to the culturally and structurally appropriate uses of the language. One such study, which focused on the effectiveness of a particular type of output-focused classroom instruction on L2 intercultural pragmatic development, was conducted by Jernigan who examined the effectiveness of video-based, pragmatic instructional units that included an output-focused activity to 
improve pragmatic awareness and pragmatically appropriate production (2). The results revealed that video-based instructional units are a useful component of communicative instruction (Jernigan 8). Similarly, in a study by Birjandi and Derakhshan, videos proved to be useful tools that could create meaningful settings for students to produce contextually appropriate language by bringing real-life situations to the classroom environment, which would raise learners ' awareness concerning various pragmatic aspects (80).

The motto of the 1980s, "communicative competence", actually showed how important it is to sound "natural" in a foreign language. Although today, emulating native speaking is not the primary aim of most English classes, inauthentic usage of language can very often lead to misunderstandings or communication breakdowns, and it is important to identify the reasons why breakdowns in communication occurs, especially in a spoken English-oriented course. No matter how proficient a language learner is, if they have difficulty producing socially appropriate sentences, their ability to negotiate the intended meaning is hindered. In linguistic terms, these inequivalent forms or awkward paraphrases cause a mismatch in illocutionary with perlocutionary forces. For this reason, the present study aimed to explore the way in which students use context to develop an awareness of culture-specific expressions. And in so doing inform us about their needs at these junctures and ways in which we can enhance students 'ability to produce contextually appropriate language.

\section{Research Design}

Our study sought to investigate the answer to the following research questions:

- What are the most common challenges students face when they encounter and learn to confidently use culture-laden fixed expressions?

- What impact do" muted videos" have as an intervention on students 'selfperception of their proficiency as authentic language users?

\section{Participants}

Study participants were 72 students enrolled in an oral communicationoriented English language course offered as a must course at Middle East Technical University, an English-medium university in Turkey. They were chosen according to the convenience sampling method known as" availability" sampling (Creswell, 2013). Volunteer participants responded to both the online pretest and the posttest. Similarly, 30 students volunteered to attend the focus group interviews held in three different sessions (5-6 students in each focus group). Of these 30 students were engaged in social studies undergraduate programs, and 42 students in other science related programs. The ages of the participants ranged between 19-24, and the average age was 20.5. By sex 47 females and 25 males participated. Most were mainly considered to be at B2 level according to the CEFR classification of language attainment since to be able to take the course the research was conducted in, they would have to pass the standardized university proficiency exam with 59.5/100 or get 75 at the TOEFLIBT exam, or 6.0 in the IELTS exam according to the Equivalence Table for 
English Language Exams recognized by the university council for undergraduate and graduate students ("Eşdeğerlik Tablosu").

\section{Data collection tools}

Our data collection tools were designed according to several criteria. The first was the observations of the researchers who both have over 20 years of experience in teaching English at a tertiary level at an English-medium university, $10 \%$ of whose student population are international students ("METU at a Glance"). Both researchers have identified the use of "Turkish English", a rather non-native sounding, inauthentic, and mostly word-to-word translationlike English use among students. The required English courses students are offered during their undergraduate years teach academic reading, writing, and speaking conventions, hence students are not exposed to authentic language use in daily life contexts, such as shopping, borrowing books from the library, paying the bill at a restaurant, being admitted to a hospital, engaging in small talk with a neighbor, etc. Even when assigned role plays, the tasks usually require the use of accurate, grammatical full sentences uncommon in authentic spoken language. Yet, although the observations and experience of the researchers are of significant value, we still conducted a needs analysis research in class through muted videos and excerpts from film scenes, some of which can be seen on the following YouTube playlist, https://shortest.link/mutedvideos. We also conducted a needs analysis task in which students came up with suggestions as to what the speaker said when the instructor paused the video. It was observed that the students came up with sentences usually too long for the time given in the video and sentences that did not fit the expressions of the speaker, or the previous or the next utterance in the dialogue, such as the one below:

A: You idiot! [When in fact a greeting speech act would have fit the context]

B: Nooo!

A: You found a shirt from your grandfather's gardrope [The Turkish word for wardrobe]? To chat with a real girl, wear [dress] like a real man!

[A slaps B on his cheek.]

B: Wow! [inappropriate exclamation after being slapped on the cheek.]

C: So, what are we doing? [At the shoe store, the salesman is speaking, meaning "How may I help you?"]

The needs analysis session provided many such examples of language use which were not grammatically problematic but did not contextually fit with the situation in which they were uttered.

The researchers developed a self-observation survey to be administered as the pretest, and the participants answered this online. The Likert-type questions used can be seen in Table 4. The survey was used as a post-test to see if there was a significant change in students 'perception of their contextual language use 
proficiency. Although the researchers initially had prepared a lengthy online survey to serve as the pre and post-tests, upon receiving feedback from two colleagues, they shortened the tests and preferred to discuss the questions further during focus group interviews.

Another data collection tool was the muted videos to which the students added voiceovers at the end of the intervention. Students were free to choose the video clips they would respond to, but they were also provided with options on a YouTube playlist prepared by the researchers that enabled them to choose scenes from movies and then muting them. The scenes were mostly related to the theme in the coursebook of the course, which was "marketing". However, students were also free to add voiceovers to scenes of their own choice as well. They were asked to add voice over comments to a 5-minute scene working in groups. As it was very difficult to arrange groups with equal numbers of characters in the scenes, most students acted out different characters several times when adding the voiceovers.

After the posttest was administered, semi-structured focus group interviews were conducted with 30 volunteering students to learn more about the effect of the experience the participants went through. The main aim was to investigate the views of the students regarding the intervention. Below are the questions asked during the focus group interviews to learn about the participants' perceptions of the effectiveness of the intervention:

- How proficient did you feel about using culture-specific expressions before the course?

- How proficient do you feel about using culture-specific expressions now?

- Do you think you have benefitted from the muted video tasks? If so, in what ways?

\section{Intervention}

The intervention lasted two months. Each week during the meeting hours of the spoken English course, which is offered 3 hours a week, the researchers played and paused the muted videos or videos that were dubbed previously by other students to discuss the appropriateness of their context-based, formulaic authentic language use. Some of the videos used during this training period can be accessed using the following YouTube playlist https://shortest.link/voicedmutedvideos. In the initial stage of the intervention, the participants discussed which phrases sounded authentic or instead as if they were word-to-word, direct translations of what they would have said in their native tongues. The students also identified those utterances that did not abide by the spoken language rhetoric norms in the videos formerly dubbed by other students, such as full, formal, and long sentences. After having studied some videos, also as part of the intervention, the participants worked on voicing muted 5-minute scenes from movies - bearing in mind the constructs of successful communication in a given context using authentic language. The intervention aimed at developing an awareness of the context, the peripheral details in the context, and the identity of the interlocutors engaged in the 
dialogues. Class discussions focused on the details of the setting, the facial expressions, and the gestures of the interlocutors, and any detail that would give clues about the expected utterances the characters in the movie scenes made. The objective of the intervention was to sensitize the participants towards phrases that are both culture and context-bound, such as "my condolences, take care, take it easy, or how may I help you?" As can be seen in the list below, the fixed utterances that came up during the intervention cannot be categorized as speech acts because some of them are signposts, exclamations, or fixed expressions. The list of utterances the intervention focused on can be seen in Table 1.

Table 1

List of some of the authentic context-dependent utterances the intervention focused on

\begin{tabular}{|l|l|}
\hline Authentic phrases & Students' suggestions \\
\hline Keep the change. & The rest is not important. \\
How may I help you? & What do you want? \\
Put it on my card. & I will pay with my credit card. \\
How did you do? & Does the sweater you tried fit you? \\
Did you find everything ok? & Is there anything you want? \\
License and registration & Give me your documents. \\
Say when & You should tell me when I should stop \\
adding more food to your plate. \\
Can I tempt you with anything? & What would you like to eat? \\
\hline
\end{tabular}

\section{Data Analysis}

The study had two main research questions:

- What were the most common challenges students faced when producing culture-laden fixed expressions?

- What was the impact of the "muted videos" intervention on students 'selfperception of their authentic language use proficiency?

To answer the first question on the most common challenges the students faced, both the videos that the participants added voiceover to, and the focus group interviews were analyzed. The videos were analyzed by keeping a tally of the frequency of inauthentic, awkward language. The researchers did not focus on the accuracy of structure in the language produced by the participants. The researchers undertook the analysis separately and then compared their findings by discussing the items, which required resolving a disagreement on whether they would qualify as inauthentic expressions or not. These phrases were also discussed with a native speaker to enhance interrater reliability. To triangulate the data, the focus group interview notes were also analyzed through content analysis. The focus group interview data was then merged with the challenges observed in the videos and reported thematically. 
The pre and post-tests on the participants 'self-perception of their culture-laden formulaic expressions were analyzed with descriptive statistics to answer the second research question. The results of the focus group interviews also helped in interpreting the statistical data. Thirty volunteering participants were interviewed in small groups (5-6 students in each group) after the intervention, and the posttest was administered at the end of the intervention period. The interviews, including four questions, were all audio-recorded, the data was later transcribed, and the content was analyzed to determine common emerging themes.

\section{Results}

In total, about 30 videos were analyzed by the researchers. They were selected according to a random selection method whereby each video had an equal chance to be selected. The researchers observed that the data was saturated after the 30th video. Accordingly, Table 2 shows the most common challenges the participants faced and what they brought up in the focus group interviews.

Table 2

Types and frequencies of inauthentic language use

Type of inauthentic language Frequency

word-to-word translations from the native language 18

Use of formal written language with long full 12 sentences

Overgeneralizing the usage of verbs and adjectives in 10 Turkish

Unfamiliarity with the formulaic expression used in 10 the context

Direct, word-to-word translations from the native language. Most cases were about direct translations from L1, which were not appropriate in L2. For example, one features a teacher who finally stops speaking after a long monologue, before one of the students says, "are you done?". Sadly such a response is inappropriate in the context because the student only meant to ask whether the class was dismissed, without being offensive. Another example given during the intervention is "bless you". In their L1, Turkish students might want to translate the Turkish expression used after somebody sneezes in English and would say "live long", which would not sound authentic at all. Similarly, in Turkish, "I am sorry" is also not a culturally appropriate, fixed expression to use to extend condolences in such a situation.

In another example, a teacher is said to be approaching a student and saying, "Where are you?", which sounds awkward because the teacher can readily see where the student is. Again a negative transfer from L1. The phrase is actually the translation of what one would say in Turkish to mean "How far along are 
you?" Another representative example from voiced videos was when adding voiceovers to the salesperson in a store asking, "What are you looking for?" The question sounds natural in Turkish; however, it is uncommon in English, because the salesperson would instead use phrases such as "How're you doing?", "How are we doing today", "Do you need any help with anything?", "Would you like me to show you anything?", "What are we looking for today?", "How may I help you?" or "Can I help you with something?" In the interviews, the participants reported that they did not expect the language they used to be formulaic phrases in L2 because they only realized that the same expressions were formulaic when they needed to translate them. Most students suggested that movies and shows helped them acquire a sense of authentic language. Participant E stated that he very often says "can be" instead of "it's possible" because he translates the Turkish phrase in his mind - ignoring whether it would work in English or not. Whereas the word "may" is more appropriate than "can" in this context. Participant F's answer was very representative of the other's opinion in the focus groups: "I felt that the language we used sounded awkward because I had never heard it used on Netflix."

Use of formal written language with long full sentences. Our study found that students are more familiar with written English as they very often endeavored to make full, accurate, and long sentences when adding voiceovers to the videos. For example, "Have you found the right size?" or "Would you like me to measure you?", or "Did you find everything ok?" are more natural utterances used when the salesperson in the movie scene is inquiring about whether the garment the character in the scene has tried on in the fitting room fits or not. Most of the participants in the study instead used long and full sentences such as "Did the sweater you tried on fit your size?" or "Did you like the sweater when you tried it on?" Another example of making a long and accurate full sentence when asking the price of a necklace is as follows: "I am wondering how much that necklace is." instead of "Excuse me, how much is this?" During the interviews, too, the students expressed that they attached more importance to whether the question they formulated was accurate grammatically or not. Although most of the students did use grammatically accurate sentences, it was not common to use the present tense, which would have been the more authentic choice, such as "How do you like it?", or "That looks good on you."

Another example is about paying for something with a credit card: instead of "Can you charge $\$ 200$ to this card?", the exact translation from Turkish was used, which would be "Can you draw $200 \$$ from this card?". In the focus groups, the participants pointed out their lack of competency in spoken discourse and repeatedly stated that they studied written English rather than spoken English in their EAP courses because they had had to take written exams, both standardized and classroom tests. Importantly, for the majority of participants, this was the first English course they were attending throughout their formal education that focused on the acquisition of spoken English.

Overgeneralizing the usage of some adjectives and verbs in Turkish. When thanking the man who just opened the door for them, the students used the 
following expression, "Thank you, you are a very polite person!" However, "You are a gentleman" is a fixed and more natural expression that can replace "a polite person". Another adjective that the students used very often when dubbing the movie scenes that sounded inauthentic was the word "beautiful". Because of negative transfer from Turkish, the participants tended to use the word beautiful as an adjective that collocates with "activity, presentation, class, meal and comment" when they were not referring to the appearance but the general good quality of the nouns. Another common mistake is the frequent use of some verbs, which lead to ungrammatical utterances. To exemplify the verbs that were used without any object following them, "to deserve" can be given. Students tended to use the verb deserve as "You deserve" instead of "You deserve it." Another transitive verb "believe" was also used without its object again: "Can you believe?", which can easily lead to fossilization if left uncorrected.

Unfamiliarity with the formulaic expression used in the context. Both in the focus group interviews and in the videos that the participants voiced, some authentic formulaic phrases were not used simply because they were unfamiliar to the students. Some examples of such phrases can be seen in the table below.

Table 3

List of some of the authentic, context-dependent utterances the participants were not familiar with

\begin{tabular}{|l|l|}
\hline Authentic phrases & Students' suggestions \\
\hline Knock knock? Who is it? & -- \\
You are under arrest! & I will send you to prison. \\
With badge and everything & He really was a policeman. \\
No further questions, your & I don't have anything else to ask. \\
honor. & I have been using this medicine. \\
I've been on... (medicine name) & Definitely, I will pay. \\
It's my treat. & When we look back,... \\
In hindsight,... & I accept to compete with you. \\
Challenge accepted! & I will tell you shortly,... \\
Long story short,... & Then I forgot myself... \\
In the heat of the moment... & Send me where you are. \\
Drop me a pin. & The danger has passed. \\
We are clear. & \\
& \\
\hline
\end{tabular}

The findings for the second research question about the impact of the "muted videos" intervention on students 'self-perception of their authentic language use can be observed in Table 4 below. 
Table 4

Students 'perceptions of their contextual authentic language competency

\begin{tabular}{|l|l|l|l|l|}
\hline \multirow{2}{*}{ Likert-type Items } & \multicolumn{2}{|c|}{ PreTest } & \multicolumn{2}{c|}{ PostTest } \\
\cline { 2 - 6 } & M & SD & M & SD \\
\hline - I can use formulaic phrases in the right context. & 3.7 & 0.7 & 4.5 & 0.5 \\
\hline - I have a sufficient vocabulary for coping with \\
$\quad$ everyday situations.
\end{tabular}

Although the perception of students 'own proficiency themselves would not provide an objective measure, sensitivity towards authentic context-dependent formulaic expression use is difficult to measure with a scale, especially because the intervention was too short in duration to expect a competency change. However, it is important to value participant perceptions because - once they know that some language they produce is grammatically accurate but does not fit the context - they can use the internet to readily search on portions of phraseology that may be popularly used in TV shows, movies, online videos, and real-life settings. In this way they can start to circumvent the bias against listening and speaking and emphasis on reading and writing so prevalent in their L2 course books. The small pretest which was given before the intervention shows that students did not perceive themselves as proficient in formulaic, culture-laden language use - yet after the intervention, their perception changed slightly. The mean score for the Likert-type questions where five stood for "strongly agree" and one represented "strongly disagree" increased. This indicates an increase in the participating students 'self-efficacy beliefs about their use of culture-specific expressions in appropriate contexts after the intervention.

The overall impression of the participants regarding the intervention was mostly positive. While some common themes for the pre-intervention period 
revolved around being "unskillful" or "incompetent", these themes turned out to be more positive ones after the intervention. The post-intervention themes included being "more knowledgeable" or sounding "more real-like" or "nativelike." The participants also pointed out that they had become more attentive while watching a television series or movies in English after the course. In this sense, it can be concluded that, in line with Schmidt's Noticing Hypothesis, consciousness-raising activities helped students to notice and focus more on culture-laden expressions occurring in their authentic settings ("Consciousness" 25). The muted video tasks also contributed to developing selective attention in that they reported noticing fixed phrases, collocations, phrasal verbs, and even exclamations in English. Such awareness suggests that participants are more likely to seek out and endeavor to use such phrases and expressions in future.

\section{Discussion and Conclusion}

Teaching pragmatics and the sociopragmatic aspects of a language is a quite challenging task for language teachers, as such elements are basically bound to cultural contexts. When the language is, especially taught in a second-language context, it is more probable that learners will be exposed to socially appropriate forms of the language structures - taught and practiced in class outside the classroom atmosphere in its natural settings. However, when considering the sociopragmatic aspects of a language, learners in a foreign language context may be disadvantaged when they are sublimely or exclusively come to spend on course books or the input that arises in the classroom. In such environments, language learners face significant challenges such as large classes, limited contact hours, and little opportunity for intercultural communication with native speakers and access to authentic materials, search tools and life-long learning skills that impede pragmatic learning (Rose, "Teachers and Students").

To remedy such obstacles in language classes in EFL settings, teachers need to provide learners with extended opportunities to receive contextualized, pragmatically appropriate input. In line with the present study, the results of some other studies have also shown that, as an extracurricular activity, teachers can ask their students to analyze video clips from a pragmatic vantage point. Since videos can simulate real-life situations that seem to help students to authenticate real-life by observing interaction between native speakers. Indeed, when they readily go on to acquire an awareness of language use that has closest approximation to real-life situations, they are emboldened to adopt it unlike anything that they previously encountered in the classroom environment where at most, they typically are only able to glean limited pragmatic aspects of the language they are trying to learn (Jernigan 2; Birjandi and Derakhshan 80). It can, therefore, be strongly suggested that video-driven vignettes may be useful to expose students to the pragmatic aspects of the target language. This teaching technique may not only provide learners with real-life pragmatics comprehension but also may compensate for the inadequacy of textbooks, limited contact hours, and classroom conversations.

Pragmatic competence is one of the fundamental abilities to be developed and improved in any language learner. It enables matching utterances with contexts 
in which they are appropriate. Therefore, it has been suggested to teach pragmatics in teacher education programs to educate students who can produce socially appropriate language for the situations they encounter. Unfortunately, there is not a single best way to teach pragmatics. However, in the light of studies conducted, some suggestions can be provided.

According to Schmidt's Noticing Hypothesis, any target L2 feature needs to be noticed by the learner for learning to occur ("Consciousness" 25). Because more attention results in more learning, "attention must be directed to whatever evidence is relevant for a particular learning domain, i.e., that attention must be specifically focused and not just global" (Schmidt, "Attention", 30). By extending his hypothesis, Schmidt adds, "to acquire pragmatics, one must attend to both the linguistic form of utterances and the relevant social and contextual features with which they are associated". This idea has implications for language classrooms. As input precedes production, language learners should first be exposed to sample authentic language uses to serve as models in the actual classrooms before they are expected to produce similar utterances. When instructors employ more perception-focused approaches to pragmatics instruction at earlier stages of language development, the imbalance between grammatical and pragmatic development may be overcome in later stages. As the results of the study also revealed, students may benefit from being directed to notice socially appropriate language through the use of consciousness-raising, video-driven prompts. Such scenes from movies, dramas, or plays often serve as a rich source of pragmatic input because they contain a variety of conversational exchanges in which the speaker's reply does not provide a straightforward answer to the question.

Having gone through the first phase of noticing, it is time for language learners to be prompted to produce similar pieces of language that will fit into the contexts they are used in. As is the case in this study, the use of muted videos might serve as a tool in which learners will be asked to actively get involved in opportunities for communication or problem-solving. Consistent with the results of Roever's research, such an instruction will benefit language learners for pragmatic development (573). Therefore, the use of video-based teaching is recommended as an instructional technique in second language learning settings to teach the complexities of pragmatics.

In addition, all interventional studies are somehow relative and prone to subjectivity as they basically depend on learners 'individual variables, such as motivation, age, and language proficiency level. The intervention used in this study proved to be beneficial for students at this age group and at this language proficiency. However, for the results to be generalized for other language learning contexts, it might be advised to replicate this study in different educational settings with learners from various age and language proficiency levels.

The present research investigated the effectiveness of an intervention that concentrated on raising students 'awareness on fixed, contextualized, authentic phrases in English via a muted video task. The participants were asked to add 
their voiceovers to muted movie scenes provided by the researchers to differentiate between the different colloquial uses of fixed phrases that would not always translate into the target language. The participants undertook this intervention process over a period off two months in which they first worked on acceptable and unacceptable fixed expressions in certain contexts and then went on to produce culturally and contextually appropriate, authentic phrases by themselves to develop sociolinguistic awareness. The results of the study showed that the students benefited from the experience, and the intervention made a meaningful improvement in the students 'awareness of authentic, contextual formulaic expressions. The current study was conducted within the scope of an English-oriented spoken course at the tertiary level. The intervention might also have produced more reliable results if more time was available to allocate for the treatment. Therefore, though the results point to an increase in students 'pragmatics awareness and indicate better outcomes in the posttest, a delayed posttest could be applied in further studies that could yield noteworthy results.

\section{Works Cited}

Austin, John Langshaw. How to Do Things with Words. 1st ed., Oxford University Press, 1962.

Barron, Anne. "Variational Pragmatics in The Foreign Language Classroom." System, vol 33, no. 3, 2005, pp. 519-536.

Berns, Margie S. "Review of The Book 'The Functional-Notional Approach: From Theory to Practice'". TESOL Quarterly, vol 18, no. 2, 1984, pp. 325-329.

Birjandi, Parviz, and Ali Derakhshan. "Pragmatic Comprehension of Apology, Request and Refusal: An Investigation on The Effect of Consciousness-Raising VideoDriven Prompts." Applied Research on English Language, vol 3, no. 1, 2014, pp. 6786.

Brown, H. Douglas. Teaching by Principles: An Interactive Approach to Language Pedagogy. 1st ed., Prentice Hall Regents, 1994.

Brown, H. Douglas. Principles of Language Learning and Teaching. 5th ed., Pearson Education, 2007.

Canale, Michael, and Merrill Swain. "Theoretical Bases of Communicative Approaches to Second Language Teaching and Testing." Applied Linguistics, vol 1, no. 1, 1980, pp. 1-47.

Davies, Catherine, and Tyler, Andrea. "Discourse Strategies in the Context of Crosscultural Institutional Talk: Uncovering Interlanguage Pragmatics in the University Classroom." In Kathleen Bardovi-Harlig and Beverly Hartford (Eds.), Interlanguage Pragmatics: Exploring Institutional Talk, pp. 133-156, Routledge, 2005.

DeCapua, Andrea and Ann Wintergerst. Crossing Cultures in The Language Classroom. 1st ed., University of Michigan Press, 2004.

Hall, Edward. The Silent Language. 1st ed., Doubleday, 1959.

Hymes, Dell. On Communicative Competence. Unpublished manuscript, University of Pennsylvania, 1972.

Kasper, Gabriele, and Roever, Carsten. Pragmatics in second language learning. In Eli Hinkel (Ed.), Handbook of Research in Second Language Teaching and Learning, pp. 317-334, Lawrence Erlbaum Associates, 2005. 
Skandera, Paul, ed. by. Phraseology and Culture in English. 1st ed., Mouton De Gruyter, 2007.

Jernigan, Justin. "Output and English as a Second Language Pragmatic Development: The Effectiveness of Output-Focused Video-Based Instruction". English Language Teaching, vol 5, no. 4, 2012, pp. 2-14. Canadian Center Of Science And Education, doi:10.5539/elt.v5n4p2.

"Sayılarla - ODTÜ". METU At A Glance, http://ilkbakista.odtu.edu.tr/english/\#section1.

"ODTÜ Tarafından Kabul Edilen İngilizce Yeterlik Sınavları Eşdeğerlik Tablosu”. ODTÜ Öğrenci Isssleri Daire Başkanlığı, 19 March 2021, https://oidb.metu.edu.tr/tr/odtu-tarafindan-kabul-edilen-ingilizce-yeterliliksinavlari-es-degerlik-tablosu.

Paulston, Christina Bratt. "Linguistic and Communicative Competence." TESOL Quarterly, vol 8, no. 4, 1974, pp. 347-362. JSTOR, doi:10.2307/3585467.

Roever, Carsten. Teaching and testing pragmatics. In Doughty, Catherine, and Michael Long, ed. by. The Handbook of Language Teaching. 1st ed., Wiley-Blackwell, 2009, pp. 560-577, Wiley, http://dx.doi.org/10.1002/9781444315783

Rose, Kenneth. Pragmatic consciousness-raising in an EFL context. In Bouton, Lawrence, and Yamuna Kachru, ed. by. Pragmatics and Language Learning. 5th ed., University of Illinois at Urbana-Champaign, 1994, pp. 52-63.

Rose, Kenneth. Teachers and students learning about requests in Hong Kong. In Eli Hinkel, ed. by. Culture in Second Language Teaching and Learning. Cambridge University Press, 1999, pp. 167-180.

Sapir, Edward. In Mandelbaum, David, ed. by. Selected Writings of Edward Sapir In Language, Culture and Personality. 1st ed., University of California Press, 2021.

Schmidt, Richard. Consciousness, learning and interlanguage pragmatics. In Kasper, Gabriel, and Blum-Kulka, Shoskena, ed. by. Interlanguage Pragmatics. Oxford University Press, 1993, pp. 21-42.

Schmidt, Richard. Attention. In Robinson, Peter, ed. by. Cognition and Second Language Instruction. Cambridge University Press, 2001, pp. 3-33.

Wagner-Gough, Judy. "Comparative Studies in Second Language Learning." CALERIC/CLL Series on Languages and Linguistics, vol 26, 1975. ERIC, https://files.eric.ed.gov/fulltext/ED107157.pdf.

Wilkins, David Arthur. Notional Syllabuses. 1st ed., Oxford University Press, 1976.

Woods, Rebecca. "Investigating the Syntax of Speech Acts: Embedding Illocutionary Force.” PhD thesis, University of York, 2016. 